踝 


\section{Progress in Mathematics}

Volume 102

Series Editors

J. Oesterlé

A. Weinstein 


\section{Séminaire de Théorie des Nombres, Paris, 1989-90}

Sinnou David

Editor

Springer Science+Business Media, LLC 1992 
Sinnou David

Département de Mathématiques

Université de Paris-Sud

Centre d'Orsay

F-91405 Orsay Cedex

France

"The Library of Congress has catalogued this

serial publication as follows:".

Séminaire Delange-Pisot-Poitou.

Séminaire de théorie des nombres/Séminaire Delange-Pisot-

Poitou. — 1979-80- — Boston: Birkhäuser, 1981-

v.; $24 \mathrm{~cm}$. - (Progress in mathematics)

Annual.

English and French.

Continues: Séminaire Delange-Pisot-Poitou. Séminaire Delange-Pisot-Poitou: [exposés]

1. Numbers, Theory of - Periodicals. I. Title. II. Series: Progress in mathematics (Boston, Mass.)
QA 24.S37a
$512.705-\mathrm{dc} 19$
85-648844
Library of Congress
[8510]
AACR 2 MARC-S

CIP-Kurztitlelaufnahme der Deutschen Bibliothek

Séminaire de théorie des nombres:

Séminaire de théorie des nombres.

Teilw. auf d. Hauptitels. auch : Séminaire Delange-

Pisot-Poitou

1989/90. Paris 1989-1990. -1991.

(Progress in mathematics ; Vol. 102)

ISBN 978-1-4757-4270-1 ISBN 978-1-4757-4269-5 (eBook)

DOI 10.1007/978-1-4757-4269-5

NE: GT

Printed on acid-free paper.

(c) Springer Science+Business Media New York 1992

Ursprünglich erschienen bei Birkhäuser Boston 1992

Softcover reprint of the hardcover 1st edition 1992

All rights reserved. No part of this publication may be reproduced, stored in a retrieval system, or transmitted, in any form or by any means, electronic, mechanical, photocopying, recording, or otherwise, without prior permission of the copyright owner.

Permission to photocopy for internal or personal use of specific clients is granted by Birkhäuser Boston Springer Science+Business Media, LLC.

for libraries and other users registered with the Copyright Clearance Center (CCC),provided that the base fee of \$0.00 per copy, plus \$0.20 per page is paid directly to CCC, 21 Congress Street, Salem, MA 01970, U.S.A. Special requests should be addressed directly to Springer Science+Business Media, LLC.

ISBN 978-1-4757-4270-1

Camera-ready copy prepared by the editor using TeX. 
Séminaire de Théorie des Nombres

Paris 1989-90

\section{Contents}

Une remarque à propos des cycles de Hodge de type $C M$

Y. ANDRÉ

Galois representations and cohomology of $G L(n, \mathbf{Z})$.

A. $A S H$

Modular forms and abelian varieties

D. BLASIUS

Sommes de Kloosterman généralisées : l'équation fonctionnelle

M. CARPENTIER

On the hermitian structure of Galois modules in number fields and Adams operations.

B. EREZ

Searching for Solutions of $x^{3}+y^{3}+z^{3}=k$

R. HEATH-BROWN

Une généralisation d'un théorème de Terjanian

Y. HELLEGOUARCH

Integer points in a domain with smooth boundary

M.N. HUXLEY

Estimates for coefficients of $L$-functions. III

W. DUKE and H. IWANIEC

Principe de Hasse cohomologique

U. JANNSEN

Classes des corps surcirculaires et des corps de fonctions.

J.-F. JAULENT et A. MICHEL

Ideal Class Groups and Galois Modules....

W.C. W. LI

Propriétés arithmétiques des substitutions.

C. MAUDUIT 
Galois theoretic local-global relations in nilpotent extensions of algebraic number fields.

K. MIYAKE

La racine 12-ième canonique de $\Delta(L)^{[L: L] / \Delta(L)}$

G. ROBERT

$P_{2}$ dans les petits intervalles.

J. WU 
Les textes qui suivent sont pour la plupart des versions écrites de conférences données pendant l'année 1989-90 au Séminaire de Théorie des Nombres de Paris. Ce séminaire est organisé par la S.D.I.6180 du C.N.R.S. qui regroupe des arithméticiens de plusieurs universités et est dotée d'un conseil scientifique et éditorial. Ont été aussi adjoints certains textes dont la mise à la disposition d'un large public nous a paru intéressante. Les articles présentés ici exposent soit des résultats nouveaux, soit des synthèses originales de questions récentes; ils ont en particulier tous fait l'objet d'un rapport.

Ce recueil doit bien sûr beaucoup à tous les participants du séminaire et à ceux qui ont accepté d'en réviser les textes. Il doit surtout à Monique Le Bronnec qui s'est chargée du secrétariat et de la mise au point définitive du manuscrit; son efficacité et sa très agréable collaboration ont été cruciales dans l'élaboration de ce livre.

Pour le Conseil éditorial et scientifique S. DAVID 